\title{
Pengaruh Jus Rumput Laut (Eucheuma Sp) terhadap Peningkatan Kadar Hb Ibu Hamil Trimester I dengan Anemia
}

\section{Effect of Seaweed Juice (Eucheuma Sp) on Increased Hb Levels in First Trimester Pregnant Women with Anemia}

\author{
Sofia Mawaddah ${ }^{1}$, Rabiatul Adawiyah ${ }^{2}$ \\ Jurusan Sarjana Terapan Kebidanan, Poltekkes Kemenkes Palangka Raya, Indonesia
}

\section{ARTICLE INFO}

\section{Article history}

Received date

10 May 2021

Revised date

20 Jun 2021

05 Aug 2021

Accepted date

23 Nov 2021

Keywords:

Anemia;

Pregnant women;

Seaweed.

Kata kunci:

Anemia;

Ibu hamil;

Rumput laut.

\author{
ABSTRACT/ ABSTRAK
}

The effect of anemia in pregnancy is not good for the mother, both during pregnancy, childbirth, and in the puerperium. One of the foods that contain iron is seaweed. Seaweed (Eucheuma sp) is one of the foodstuffs that contain several intermediate compounds needed in the synthesis of hemoglobin such as iron, protein, and vitamin B complex. The purpose of this study was to determine the effect of seaweed juice (Eucheuma sp) on increasing hemoglobin levels of pregnant women in the first trimester of anemia. This study was a pre-experimental study with a one-group pretest-posttest design with a sample of 30 pregnant women in the first trimester who met the inclusion criteria of the study. Researchers measured $\mathrm{Hb}$ levels before after being given seaweed juice, the statistical test used was the Paired T-Test test, $p$-value $=0,000$. The conclusion from this study was that seaweed juice could increase $\mathrm{Hb}$ levels in first-trimester pregnant women with anemia.

\begin{abstract}
Pengaruh anemia dalam kehamilan kurang baik bagi ibu, baik dalam kehamilan, persalinan maupun dalam masa nifas. Salah satu makanan yang mengandung zat besi adalah rumput laut. Rumput laut (Eucheuma $s p$ ) merupakan salah satu bahan makanan yang mengandung beberapa senyawa antara yang diperlukan dalam sintesis hemoglobin seperti zat besi, protein dan vitamin B kompleks. Tujuan penelitian mengetahui pengaruh jus rumput laut (Eucheuma $s p$ ) terhadap peningkatan kadar hemoglobin ibu hamil trimester I anemia. Penelitian ini merupakan penelitian pre-eksperimen dengan rancangan one group pretest-postest dengan jumlah sampel $30 \mathrm{ibu}$ hamil trimester I yang memenuhi kriteria insklusi penelitian. Peneliti mengukur kadar hb sebelum sesudah diberikan jus rumput laut. Uji statistik yang digunakan yaitu uji Paired T-Test didapatkan nilai $p$-value $=0,000$. Jus rumput laut dapat meningkatkan kadar $\mathrm{Hb}$ pada ibu hamil trimester I dengan anemia.
\end{abstract}

Corresponding Author :

Sofia Mawaddah

Jurusan Sarjana Terapan Kebidanan, Poltekkes Kemenkes Palangka Raya, Indonesia

Email: sofizline@gmail.com

\section{PENDAHULUAN}

Anemia pada kehamilan sering disebut potential danger to mother and child (berpotensi membahayakan ibu dan anak), sehingga penangananan anemia memerlukan perhatian serius dari semua pihak yang terkait dalam pelayanan kesehatan pada lini terdepan (Manuaba, 2012).

Pengaruh anemia dalam kehamilan kurang baik bagi ibu, baik dalam kehamilan, persalinan maupun dalam masa nifas. Penyulit yang dapat timbul akibat anemia seperti abortus, partus prematurus, partus lama karena inersia uteri, perdarahan post partum karena atonia uteri, 
infeksi, dekompensasi kordis bahkan hipoksia akibat anemia dapat menyebabkan syok dan kematian bagi ibu pada persalinan sulit, walaupun tidak terjadi perdarahan (Prawirohardjo, 2011). Sedangkan akibat adanya anemia pada ibu hamil sangat berpengaruh pada janin karena menyebabkan terjadinya hambatan tumbuh kembang janin bahkan kematian janin intra uteri (Manuaba, 2012).

Ibu hamil diajurkan untuk mengkonsumsi paling sedikit 90 tablet besi selama masa kehamilan. Zat besi yang berasal dari makanan belum bisa mencukupi kebutuhan selama hamil, karena zat besi tidak hanya dibutuhkan oleh ibu saja tetapi juga untuk janin yang ada di dalam kandungannya. Apabila ibu hamil selama masa kehamilan patuh mengkonsumsi tablet $\mathrm{Fe}$ maka resiko terkena anemia semakin kecil Kepatuhan ibu sangat berperan dalam meningkatkan kadar $\mathrm{Hb}$. Kepatuhan tersebut meliputi ketepatan jumlah tablet yang dikonsumsi, ketepatan cara mengkonsumsi dan keteraturan frekuensi mengonsumsi tablet Fe (Manuaba, 2012).

Asam folat merupakan suplemen yang wajib diminum oleh wanita hamil, tetapi asam folat juga dapat ditemukan didalam makanan seperti sereal, sayuran berdaun hijau, pisang, melon, dan kacang-kacangan. Kekurangan asam folat juga dapat menyebabkan anemia karena berperan dalam produksi sel darah merah.

Vitamin B-12 juga merupakan vitamin yang diperlukan tubuh untuk membantu produksi sel darah merah. Meskipun beberapa wanita cukup mengkonsumsi vitamin B-12 melalui makanannya, akan tetapi mungkin saja tubuh memiliki kemampuan yang rendah dalam menyerapnya sehingga tetap kekurangan, terutama pada ibu hamil yang mengalami gangguan di usus dan diare.

Di Kalimantan Tengah, sudah mengalami penurunan walaupun tidak signifikan terlihat dari tahun 2014 jumlah kasus kematian ibu berjumlah 101 kasus, menurun lagi pada tahun 2015 dimana jumlah kasus kematian ibu yang dilaporkan sebanyak 80 kasus, dan menurun lagi pada tahun 2016 sebanyak 74 kasus dengan penyebab terbanyak akibat komplikasi dalam persalinan seperti perdarahan dan kelahiran yang sulit (Dinas Kesehatan Provinsi Kalimantan Tengah, 2016; 2017).

Tahun 2018, persentase kejadian anemia pada ibu hamil di Kalimantan Tengah adalah sebesar 14,7 \% (data PWS KIA Dinas Kesehatan Kalimantan Tengah), sedangkan di Kabupaten Kotawaringin Timur tahun 2018 angka kejadian Anemia pada Ibu Hamil sebesar 1.954 bumil $(24,1 \%)$ dan menempati urutan tertinggi dari seluruh kabupaten lain, sedangkan pada tahun 2019 sampai dengan bulan Juli angka anemia pada ibu hamil sebesar 795 orang dari 10.180 sasaran ibu hamil. (data PWS KIA dan Gizi Dinas Kesehatan Kabupaten Kotawaringin Timur, dan di wilayah kerja Puskesmas Samuda Kecamatan Mentaya Hilir Selatan angka kejadian Anemia pada Ibu Hamil pada tahun 2018 sebesar 81 kasus atau 14,8 \% (data PWS KIA Puskesmas Samuda 2018) dan pada tahun 2019 sampai dengan bulan juli ada 19 kasus atau 5,4 \% (data PWS KIA Puskesmas Samuda 2019) (Dinas Kesehatan Provinsi Kalimantan Tengah, 2018; 2019).

Untuk mencegah anemia, setiap ibu hamil diharapkan mendapatkan Tablet Tambah Darah (TTD) minimal 90 tablet selama kehamilan. Hasil Pekan Survay Gizi (PSG) tahun 2016 mendapatkan hanya 40,2\% ibu hamil yang mendapatkan TTD minimal 90 tablet, angka tersebut lebih rendah dari target nasional tahun 2016 sebesar 85\%. Di Propinsi Kalimantan Tengah angka tersebut jauh lebih rendah lagi, dimana ibu hamil yang mendapatkan TTD kurang dari 90 tablet sebesar 59,2\%. Demikian pula dengan persentase ibu hamil berdasarkan kecukupan energi, ditemukan $61,7 \%$ ibu hamil dengan defisit $<70 \%$ Angka Kecukupan Energi, dan ada 53,1\% ibu hamil dengan defisit $<80 \%$ Angka Kecukupan Protein (Kementerian Kesehatan RI, 2017)

Salah satu makanan yang mengandung zat besi adalah rumput laut. Rumput laut (Eucheuma $s p$ ) merupakan salah satu bahan makanan yang mengandung beberapa senyawa antara yang diperlukan dalam sintesis hemoglobin seperti zat besi, protein dan vitamin B kompleks. Rumput laut adalah alga makroskopik yang hidup di perairan. Layaknya alga lainnya, rumput laut tidak memiliki akar, batang, dan daun sejati. Seluruh bagian rumput laut disebut talus (thallus). Talus pada rumput laut ada yang tanpa percabangan dan bercabang-cabang dengan sifat mulai dari lunak, keras (diliputi zat kapur), seperti tulang rawan, hingga berserabut. (Nugroho BA, 2014). Rumput laut dapat diolah menjadi agar-agar, minuman segar, kue, dan bakso. Cara memperolehnya pun tidak sulit, banyak dijual di pasar tradisional maupun pasar modern (Wibowo, 2012).

Menurut hasil penelitian Rahmi (2018) ada kenaikan hemoglobin yang cukup signifikan pada ibu hamil setelah mengkonsumsi rumput laut bersamaan dengan pemberian tablet $\mathrm{Fe}$ dari pada ibu hamil yang hanya meminum tablet Fe saja tanpa rumput laut. Mayoritas hemoglobin ibu hamil sebelum diberikan rumput laut hanya 
$8,9 \mathrm{gr} / \mathrm{dl}$ setelah diberikan rumput laut meningkat menjadi 12,7gr/dl (Rahmi, 2018). Tujuan penelitian untuk mengetahui pengaruh konsumsi rumput laut (eucheuma $s p$ ) terhadap peningkatan kadar hemoglobin ibu hamil trimester I dengan anemia.

\section{METODE}

Penelitian ini menggunakan pre eksperimen dengan rancangan one group pretestpostest. Penelitian ini dilakukan di wilayah kerja Puskesmas Samuda Kecamatan Timur. Populasi target dalam penelitian ini adalah seluruh ibu hamil Trimester I dengan anemia dengan jumlah sampel $30 \mathrm{ibu}$ hamil. Teknik pengambilan sampel yaitu purposive sampling dengan memilih sampel yang memenuhi kriteria inklusi. Dalam penelitian ini alat bantu yang digunakan yaitu lembar observasi yang berisikan identitas responden dan pengukuran $\mathrm{Hb}$ awal dan $\mathrm{Hb}$ akhir responden. Peneliti memilih sampel yang termasuk kriteria insklusi dan bersedia melakuan informed consent. Sebelum diberikan jus rumput laut, peneliti terlebih dahulu mengukur kadar $\mathrm{Hb}$ ibu hamil dan pada hari ke 8 setelah responden megkonsumsi jus rumput laut, peneliti melakukan pengukuran $\mathrm{Hb}$ kembali. Responden diberikan jus rumput laut selama 8 hari.

Analisis yang digunakan dalam penelitian ini adalah analisis univariat untuk mengetahui nilai rata-rata distribusi frekuensi masing-masing variabel dan analisis bivariat dalam penelitian ini yaitu untuk mengetahui perbedaan kadar $\mathrm{Hb}$ sebelum dan sesudah mengkonsumsi Jus Rumput Laut terhadap ibu hamil dengan anemia dengan menggunakan uji dependen Paired T-test. Penelitian telah di uji etik dan disetujui oleh Komisi Etik Penelitian Kesehatan Poltekkes Kemenkes Palangka Raya dengan Nomor: 086/IV/KE.PE/2020.

\section{HASIL}

\section{Tabel 1. Distribusi Frekuensi}

\begin{tabular}{lrl}
\hline Variabel Perancu & n & \% \\
\hline Usia & & \\
$<20$ tahun & 5 & 16,7 \\
$20-35$ tahun & 12 & 40,0 \\
$\geq 35$ tahun & 13 & 43,3 \\
\hline Paritas & & \\
Primipara & 7 & 23,3 \\
Multipara & 12 & 40,0 \\
Grandemultipara & 11 & 36,7 \\
\hline Gizi Ibu & & \\
$\quad$ Gizi Normal & 14 & 46,7 \\
$\quad$ KEK & 16 & 53,3 \\
\hline
\end{tabular}

Berdasarkan tabel 1 menunjukan bahwa usia yang banyak yaitu ibu hamil berusia $\geq 35$ tahun ada 13 ibu hamil (43,3\%), paritas yang banyak yaitu ibu dengan multipara sebanyak 12 ibu hamil (40\%) dan gizi ibu dengan KEK sebanyak 16 ibu hamil $(53,3 \%)$.

Tabel 2. Rata-rata Kadar Hb Sebelum dan Sesudah Mengkonsumsi Jus Rumput Laut

\begin{tabular}{lrccccc}
\hline Variabel & Mean & SD & SE & Min & Max & n \\
\hline Hb sebelum perlakuan & 9,38 & 0,287 & 0,056 & 10,00 & 10,80 & 30 \\
Hb sesudah perlakuan & 11,99 & 0,402 & 0,084 & 11,20 & 12,50 & 30 \\
\hline
\end{tabular}

Berdasarkan tabel 2 rata-rata kadar $\mathrm{Hb}$ sebelum perlakuan adalah 9,38g/dl dan meningkat menjadi $11,99 \mathrm{~g} / \mathrm{dl}$ sesudah perlakuan, serta standar deviasi 0,287 dengan standar error 0,056 sebelum perlakuan dan sesudah perlakuan

standar deviasi 0,402 dengan standar error 0,084 . Nilai minimum 10,00 dengan nilai maximum 10,80 sebelum perlakuan dan sesudah perlakuan minimum 11,20 dengan nilai maksimum 12,50.

Tabel 3. Analisis Perbedaan Kadar Hb Sebelum dan Sesudah Mengkonsumsi Jus Rumput Laut

\begin{tabular}{crccccr}
\hline Perlakuan & Mean Paired & SD & SE & Lower & Upper & p-value \\
\hline Sebelum-sesudah & $-1,452$ & 0,356 & 0,081 & $-1,62445$ & $-1,28082$ & 0,000 \\
\hline
\end{tabular}

Berdasarkan tabel 3 didapatkan hasil ratarata kadar $\mathrm{Hb}$ sebelum perlakuan dan sesudah perlakuan mengalami peningkatan sebesar $1,45 \mathrm{~g} / \mathrm{dl}$ dengan standar deviasi 0,356 , standar error 0,081dan nilai lower -1,62445 dan upper 1,28082. Nilai $p$-value $=0,000$ berarti ada perbedaan kadar $\mathrm{Hb}$ sebelum dan sesudah mengkonsumsi jus rumput laut atau dapat disimpulkan dengan mengkonsumsi jus runput laut dapat meningkatkan kadar $\mathrm{Hb}$ ibu hamil trimester I dengan anemia 


\section{PEMBAHASAN}

Berdasarkan hasil penelitian usia yang banyak pada penelitian ini yaitu ibu hamil berusia $\geq 35$ tahun. Wanita usia subur cenderung menderita anemia dikarenakan wanita mengalami menstruasi setiap bulan, dan ini akan diperberat jika asupan zat besi dari makanan sehari-hari rendah. Wanita usia subur yang mengalami anemia gizi besi akan mudah sakit karena daya tahan tubuh yang rendah sehingga produktivitas kerja rendah.

Umur ibu yang ideal dalam kehamilan yaitu pada kelompok umur 20-35 tahun dan pada umur tersebut kurang beresiko komplikasi kehamilan serta memiliki reproduksi yang sehat. Hal ini terkait dengan kondisi biologis dan psikologis dari ibu hamil. Sebaliknya pada kelompok umur $<20$ tahun beresiko anemia sebab pada kelompok umur tersebut perkembangan biologis yaitu reproduksi belum optimal. Selain itu,kehamilan pada kelompok usia diatas 35 tahun merupakan kehamilan yang beresiko tinggi. Wanita hamil dengan umur diatas 35 tahun juga akan rentan anemia. Hal ini menyebabkan daya tahun tubuh mulai menurun dan mudah terkena berbagai infeksi selama masa kehamilan.

Berdasarkan karakteristik paritas didapatkan ibu dengan paritas multipara sebesar 12 ibu hamil (40\%). Ibu hamil yang melahirkan lebih dari 3 kali merupakan kehamilan yang beisiko tinggi karena semakin sering melahirkan semakin banyak kehilangan darah dan cadangan zat besi. Semakin banyak jumlah anak yang dilahirkan semakin tinggi resiko anemia (Mawaddah \& Muhtar, 2018).

Paritas merupakan salah satu faktor penting dalam kejadian anemia zat besi pada ibu hamil. Wanita yang sering mengalami kehamilan dan melahirkan makin anemia karena banyak kehilangan zat besi, hal ini disebabkan selama kehamilan wanita menggunakan cadangan besi yang ada di dalam tubuhnya (Salmariantity, 2012).

Paritas adalah banyaknya bayi yang dilahirkan seorang ibu, baik melahirkan yang lahir hidup ataupun lahir mati. Resiko ibu mengalami anemia dalam kehamilan salah satu penyebabnya adalah ibu yang sering melahirkan dan pada kehamilan berikutnya ibu kurang memperhatikan asupan nutrisi yang baik dalam kehamilan.Hal ini disebabkan karena dalam masa kehamilan zat gizi akan terbagi untuk ibu dan untuk janin yang dikandung Kecenderungan bahwa semakin banyak jumlah kelahiran (paritas), maka akan semakin tinggi angka kejadian anemia.
Berdasarkan gizi ibu hamil didapatkan bahwa kejadian anemia pada ibu hamil lebih besar pada ibu hamil dengan KEK atau LILA $<23,5 \mathrm{~cm}$ yaitu sebesar $(57,9 \%)$. Ini menunjukan bahwa asupan gizi yang kurang menjadi penyebab kurangnya gizi ibu hamil dan juga tingginya kejadian anemia pada ibu hamil. Salah satu faktor penyebab anemia karena kurangnya asupan zat besi pada makanan yang dikonsumsi setiap hari yang ditandai dengan kadar hemoglobin $(\mathrm{Hb})$ di bawah normal (Mawaddah \& Pratiwi, 2019).

Status gizi masa lalu dapat mempengaruhi kondisi kesehatan dimasa sekarang hingga masa yang akan datang Perempuan harus mendapatkan perhatian khusus karena nantinya mereka akan melahirkan anak. Status Gizi perempuan akan sangat mempengaruhi status gizi anak esok. Status gizi perempuan dewasa ditentukan kecukupan gizi saat remaja (Mawaddah \& Pratiwi, 2019).

Menurut Supariasa, Bakri, dan Fajar (2016) penilaian status gizi dapat dilakukan secara langsung dan tidak langsung, yaitu: pertama, penilaian status gizi langsung, adalah dengan antropometri, pemeriksaan fisik seperti gejalagejala klinis, biokimia, dan biofisik. Metode antropometri merupakan metode penilaian status gizi yang umum dipakai ditinjau dari sudut pandang gizi. Menurut Widya (2014) ada beberapa cara yang dapat digunakan untuk mengetahui status gizi ibu hamil, antara lain penilaian status gizi secara langsung dan tidak langsung. Penilaian status gizi secara langsung antara lain memantau penambahan berat badan selama hamil, mengukur LILA untuk mengetahui apakah seseorang menderita KEK dan mengukur kadar Hemoglobin ( $\mathrm{Hb})$ untuk mengetahui kondisi ibu apakah menderita anemia gizi. Penilaian status gizi secara tidak langsung yaitu survei konsumsi makanan, statistik vital, dan faktor ekologi. Survey konsumsi makanan adalah metode penentuan status gizi secara tidak langsung dengan melihat jumlah dan jenis zat gizi yang dikonsumsi.

Status gizi ibu hamil merupakan salah satu indikator dalam mengukur status gizi masyarakat. Jika masukan gizi untuk ibu hamil dari makanan tidak seimbang dengan kebutuhan tubuh maka akan terjadi defisiensi zat gizi. Kekurangan zat gizi dan rendahnya derajat kesehatan ibu hamil masih sangat rawan, hal ini ditandai masih tingginya angka kematian ibu yang disebabkan oleh perdarahan karena anemia gizi dan KEK selama masa kehamilan (Yuliastuti, 2014).

Status gizi merupakan faktor yang terdapat dalam level individu, faktor yang dipengaruhi 
langsung oleh jumlah dan jenis asupan makanan serta kondisi infeksi. Diartikan juga sebagai keadaan fisik seseorang yang ditentukan dengan salah satu atau kombinasi ukuran-ukuran gizi tertentu. Penilaian status gizi dapat dilakukan melalui empat cara yaitu secara klinis, biokimia, antropometri dan survei konsumsi makanan.

Zat besi merupakan mineral yang ditemukan dallam sel-sel darah merah (hemoglobin) dan digunakan untuk membawa oksigen dari paru-paru keseluruh tubuh Apabila asupan zat besi kurang, maka hemoglobin darah akan menurun dan terjadilah anemia. Berkurangnya zat besi pada makanan sebagai akibat dari tidak makan-makanan yang kaya akan zat besi atau ketidak mampuan tubuh untuk menyerap zat besi yang dikonsumsi (misalnya karena ada gangguan penyerapan di usus). Kebutuhan akan zat besi yang meningkat karena kehamilan itu sendiri, selain untuk produksi selsel darah merah ibu, zat besi sangat diperlukan untuk pembentukan sel darah merah pada janin. Oleh karena itu, suplemen zat besi selama kehamilan sangat diperlukan. Misalnya makanan yang kaya akan zat besi adalah daging merah/unggas, telur, sayuran berdaun hijau (seperti bayam, dan brokoli), kacang-kacangan dan biji-bijian, tahu dan tempe.

Berdasarkan hasil uji didapatkan bahwa $p$ value lebih kecil dari nilai alpha $(0,000<0,05)$ Hal ini membuktikan bahwa dengan mengkonsumsi rumput laut secara teratur dan dengan komposisi yang sesuai dapat meningkatkan kadar $\mathrm{Hb}$ pada ibu. Hasil penelitian ini sejalan dengan penelitian yang dilakukan Uluwiyatun, Runjati, dan Suwondo (2015) dimana ada pengaruh konsumsi rumput laut terhadap peningkatan kadar $\mathrm{Hb}$ walaupun tidak ada pengaruh terhadap peningkatan status Fe. Hasil penelitian ini juga didukung oleh penelitian Rahmi (2018) dimana ada kenaikan kadar $\mathrm{Hb}$ yang cukup signifikan pada ibu hamil setelah mengkonsumsi rumput laut bersamaan dengan pemberian tablet $\mathrm{Fe}$ daripada ibu hamil yang hanya meminum tablet $\mathrm{Fe}$ saja tanpa rumput laut dengan perbedaan kadar $\mathrm{Hb}$ dari sebelumnya $8,9 \mathrm{~g} / \mathrm{dl}$ menjadi $12,7 \mathrm{~g} / \mathrm{dl}$. Didukung juga oleh penelitian sebelumnya yang dilakukan oleh Noflidaputri (2018) dimana terdapat perbedaan rata-rata kenaikan kadar haemoglobin ibu hamil anemia antara kelompok eksperimen dan kelompok control dengan beda rata-rata $0,80 \mathrm{gr} / \mathrm{dl}$ dengan signifikansi p-value 0,017.

Sampai saat melahirkan, wanita hamil butuh zat besi sekitar 40mg per hari atau dua kali lipat kebutuhan kondisi tidak hamil. Masukan zat besi setiap hari diperlukan untuk mengganti zat besi yang hilang melalui tinja, air kencing dan kulit. Kehilangan basal ini kira-kira 14 ug per $\mathrm{Kg}$ berat badan per hari atau hampir sama dengan $0,9 \mathrm{mg}$ zat besi pada laki-laki dewasa dan $0,8 \mathrm{mg}$ bagi wanita dewasa. Kebutuhan zat besi pada ibu hamil berbeda pada setiap umur kehamilannya, pada trimester I naik dari $0,8 \mathrm{mg} / \mathrm{hari}$, menjadi $6,3 \mathrm{mg} /$ hari pada trimester III. Kebutuhan akan zat besi sangat menyolok kenaikannya. Hasil penelitian ini juga sejalan dengan penelitian dilakukan oleh Ayuni dan Rishel (2021), konsumsi rumput laut secara teratur ternyata memberikan efek terhadap peningkatan kadar hemoglobin pada penderita anemia. Pada ibu hamil yang mengalami anemia, selain bahan yang mudah didapatkan, mengkonsumsinya dalam jangka panjang tentu juga tidak memberikan pengaruh yang buruk terhadap kesehatan ibu hamil dan juga terhadap janin yang dikandung.

Dengan demikian kebutuhan zat besi pada trimester II dan III tidak dapat dipenuhi dari makanan saja, walaupun makanan yang dimakan cukup baik kualitasnya dan bioavailabilitas zat besi tinggi, namun zat besi juga harus disuplai darisumber lain agar supaya cukup. Penambahan zat besi selama kehamilan kira-kira 1000mg, karena mutlak dibutuhkan untuk janin, plasenta dan penambahan volume darah ibu. Sebagian dari peningkatan ini dapat dipenuhi oleh simpanan zat besi dan peningkatan adaptif persentase zat besi yang diserap.

Tetapi bila simpanan zat besi rendah atau tidak ada sama sekali dan zat besi yang diserap dari makanan sangat sedikit maka, diperlukan suplemen preparat besi. Untuk itu pemberian suplemen Fe disesuaikan dengan usia kehamilan atau kebutuhan zat besi tiap semester, yaitu trimester I: kebutuhan zat besi $\pm 1 \mathrm{mg} / \mathrm{hari}$, (kehilangan basal 0,8mg/hari) ditambah 30-40mg untuk kebutuhan janin dan sel darah merah; trimester II: kebutuhan zat besi $\pm 5 \mathrm{mg} / \mathrm{hari}$, (kehilangan basal $0,8 \mathrm{mg} / \mathrm{hari}$ ) ditambah kebutuhan sel darah merah $300 \mathrm{mg}$ dan conceptus $115 \mathrm{mg}$; dan rimester III: kebutuhan zat besi $5 \mathrm{mg} / \mathrm{hari}$,) ditambah kebutuhan sel darah merah $150 \mathrm{mg}$ dan conceptus $223 \mathrm{mg}$.

Terkait Pemberian Tablet Tambah Darah bagi ibu hamil Menurut Riskesdas (2013), hanya ada $33,3 \%$ ibu hamil yang mengkonsumsi minimal 90 TTD selama kehamilan (Badan Penelitian dan Pengembangan Kesehatan Kementerian Kesehatan RI, 2013). Sebuah studi formatif yang dilakukan di wilayah Program Kesehatan dan Gizi Berbasis Masyarakat (PKGBM) pada tahun 2014 menunjukkan bahwa hanya 54,5\% ibu hamil mengkonsumsi 90 TTD 
yang diberikan kepada mereka rata-rata TTD yang diterima dan dikonsumsi oleh ibu hamil pada trimester I adalah 32 dan 25, pada trimester II adalah 39 dan 30, dan pada trimester III adalah 37 dan 26. Alasan yang paling umum dikemukakan oleh ibu hamil untuk tidak mengonsumsi penuh dosis TTD yang dianjurkan adalah efek samping. Untuk meningkatkan konsumsi penuh TTD diperlukan penyuluhan kesehatan dengan didukung materi Komunikasi, Informasi dan Edukasi (KIE) yang tepat untuk tenaga kesehatan (Kementerian Kesehatan RI, 2015).

Menurut Permenkes RI. No. 88 (2014) tablet tambah darah merupakan tablet yang diberikan kepada wanita usia subur dan ibu hamil. Bagi wanita usia subur diberikan sebanyak 1 kali seminggu dan 1 kali sehari selama haid dan untuk ibu hamil diberikan setiap hari selama masa kehamilannya atau minimal 90 tablet.

\section{DAFTAR PUSTAKA}

Ayuni, D. Q., \& Rishel, R. A. (2021). Pemberian Konsumsi Rumput Laut (Eucheuma Spinosum) Terhadap Peningkatan Kadar Hemoglobin Pada Ibu Hamil Diwilayah Kerja Puskesmas Naras Kota Pariaman. Jurnal Ilmu Keperawatan dan Kebidanan, 12(1), 149-156.

Badan Penelitian dan Pengembangan Kesehatan kementrian Kesehatan RI. Riset Kesehatan Dasar (Riskesdas) 2013. Jakarta.

Dinas Kesehatan Provinsi Kalimantan Tengah. (2016). Profil Kesehatan Provinsi Kalimantan Tengah Tahun 2016. Kalimantan Tengah.

Dinas Kesehatan Provinsi Kalimantan Tengah. (2017). Profil Kesehatan Provinsi Kalimantan Tengah Tahun 2017. Kalimantan Tengah.

Dinas Kesehatan Provinsi Kalimantan Tengah. (2018). Profil Kesehatan Provinsi Kalimantan Tengah Tahun 2018. Kalimantan Tengah.

Dinas Kesehatan Provinsi Kalimantan Tengah. (2019). Profil Kesehatan Provinsi Kalimantan Tengah Tahun 2019. Kalimantan Tengah.

Kementerian Kesehatan RI. (2015). Pedoman Program Pemberian dan Pemantauan Mutu Tablet Tambah Darah Untuk Ibu Hamil. Jakarta. Kerjasama Kementrian Kesehatan RI dan Millenium Challenge Account-Indonesia. http://mcaindonesia.go.id/Pedoman-TTD.

\section{SIMPULAN}

Hasil penelitian ini membuktikan bahwa jus rumput laut bisa menjadi salah satu alternatif dalam upaya ibu hamil untuk memenuhi suplemen mineral zat besi dalam meningkatkan kadar $\mathrm{Hb}$. Perlunya kegiatan yang ada di pelayanan Antenatal Care (ANC) untuk ibu hamil lebih ditingkatkan yaitu petugas kesehatan memberikan penyuluhan tentang informasi kehamilan seperti informasi gizi selama hamil dan ibu diberi tablet tambah darah secara gratis serta diberikan informasi tablet tambah darah tersebut yang dapat memperkecil terjadinya anemia selama hamil.

Manuaba, I. B. (2012). Ilmu Kebidanan, Penyakit Kandungan dan KB. Jakarta: EGC.

Mawaddah, S., \& Muhtar, C. M. (2018). Kenaikan Berat Badan Ibu Hamil Terhadap Berat Lahir Bayi Di Kota Palangka Raya. Mahakam Midwifery Journal (MMJ), 3(2), 230. https://doi.org/10.35963/midwifery.v3i2.104

Mawaddah, S., \& Pratiwi, I. M. (2018). Hubungan Kadar Hemoglobin dengan Kejadian Dismenorea Pada Remaja. Jurnal Berkala Kesehatan, 4(2), 61-64.

Nugroho BA, P. E. (2014). Pengaruh Diet Ekstrak Rumput Laut (Eucheuma sp.) Terhadap Kadar Glukosa Darah Tikus Putih (Rattus norvegicus) Hiperglikemik. Media Med Indonesia, 39(3), 154-156.

Permenkes RI. (2014). Permenkes RI No. 88 Tahun 2014 Standar tablet tambah darah bagi wanita usia subur dan ibu hamil. Jakarta: Permenkes RI.

Prawirohardjo. (2011). Ilmu Kebidanan. Jakarta: PT. Bina Pustaka Sarwono Prawirohardjo.

Rahmi, R. (2018). Efektifitas Konsumsi Rumput Laut Untuk Meningkatkan Kadar Haemoglobin Pada Ibu Hamil Anemia. Jurnal Endurance, 3(1), 195.https://doi.org/10.22216/jen.v3i1.2616

Noflidaputri, R. (2018). Perbandingan Pemberian Rumput Laut (Eucheuma Sp) Dan Tablet $\mathrm{Fe}$ Terhadap Peningkatan Kadar Hemoglobin Ibu Hamil Anemia Di Puskesmas. Menara Ilmu, 12(3).

Salmariantity. (2012). Faktor-Faktor yang Berhubungan dengan Anemia pada 
IbuHamil di Wilayah Kerja Puskesmas Gajah Mada Tembilahan Kabupaten Indragiri Hilir tahun 2012. [Skripsi]. Depok: Fakultas Kesehatan Masyarakat, Universitas Indonesia.

Supariasa, Bakri, B \&amp; Fajar, I. (2016). Penilaian Status Gizi. Jakarta: EGC.

Uluwiyatun, U., Runjati, R., \& Suwondo, A. (2015). Pengaruh Konsumsi Rumput Laut (Eucheuma Sp) terhadap Peningkatan Kadar Hemoglobin. Jurnal Endurance, 3 (1), 195-199.
Wibowo. (2012). Manajemen Kinerja. Jakarta: Raja Grafindo Persada.

Widya, K. (2014). Gizi Ibu Hamil. Yogyakarta: Nuha Medika.

Yuliastuti, E. (2014). Faktor-faktor yang berhubungan dengan kekurangan energi kronis pada ibu hamil di Wilayah Kerja Puskesmas Sungai Bilu Banjarmasin. AnNadaa: Jurnal Kesehatan Masyarakat, 1(2), 72-76. 